\title{
The Possibilities of Supporting the Public Functions with Fleet and Force Tracking Systems ${ }^{1}$
}

\author{
Krisztián KÁROLY,2 András NÉMETH ${ }^{3}$
}

\begin{abstract}
The variable tracking systems for troops monitoring on field were popular for espionage in the 1980s and 1990s. Then they became essential materials for the action movies of the $21^{\text {st }}$ century. Due to the rapid development of information technologies, the different navigation methods, systems and tools, this is now a 24/7 service and can be purchased by anyone to have detections and observations of the actions of vehicles, groups of people, individuals or even animals.

From the number of variable options available for navigation, the applicable procedures are based on radio frequencies, even within that, those solutions that work in the frame of the service of global navigation satellite systems. This is due to their universalities. Gratitude to the up-to-date wireless data transfer solutions that can assure the near-real time geographical location detection of the respective moving object and individuals. Nowadays, these alternate services are widely used in many areas of public life i.e. fleet tracking or personal and property security.

The proper way of integration into the state administrational technical support subsystem of these developed technologies and the implementation of the available services can significantly increase the effectiveness of the public duties' performance, both in the area of public services and governmental organisations. These could contribute to the creation of the picture of "Good State" and to raise the standardised level of services provided to the citizens.
\end{abstract}

Keywords: Fleet and Force Tracking Systems (FTS), Global Navigation Satellite System (GNSS), radio communication and data transmission systems, public services

\section{Introduction}

Today’s society and human relations are defined by services of information technology (IT) and the mission tailored application of them. The users can distribute a significant amount of data in a faster and easier way while the costs of them are continuously

This article is supported by the ÚNKP-18-3-iv-NKE-27 New National Excellence Program of the Ministry of Human Capacities.

2 Ph.D. candidate, National University of Public Service, Faculty of Military Sciences and Officer Training, Doctoral School of Military Engineering; e-mail: krisztian.karoly@mil.hu; ORCID: 0000-0002-5835-7980

3 Ph.D., Associate Professor, National University of Public Service, Faculty of Military Sciences and Officer Training; e-mail: nemeth.andras@uni-nke.hu; ORCID: 0000-0003-2397-189X_ 
decreasing. This sector became one of the most important driving powers of globalisation and the development of world economy, as well. The quick improvement of the technical background of communication and content services generated rapid increase for the created and transmitted data within a specified unit of time. Due to the appearance of new market segments, it has dramatically changed the sales, the advertisement and the whole service industry altogether. One can easily say the importance of information was valorised in the last decade. For the proper economic decisions, more and more data needs to be processed and its efficiency is driven by its complexity and the speed of applied algorithms. These elements had an impact on other sectors as well, continuously shaping our day-to-day life. Therefore, we can call—among other things — today's society information society.

The basis of information society is the information itself that could be extracted from different sources and strictly defined and structured data mass (databases), with the help of applications using algorithms.

The achievements of information society have heavily impacted different areas of public administration, the quality of public services or the efficiency of the services of (even local) governmental organisations. Let us think about the improvement of public administration, [1] [2] the growing services of the general e-governmental client gate (“Ügyfélkapu” in Hungarian) or the registry and decision support information systems of some governmental bodies.

Nowadays in governmental offices, governmental bodies or public services, the administration is running through networks with IT $^{4}$ support, the same way how it works through other government monitored institutions like healthcare or public education. This integration level of IT services automatically pulled up the transformation of public institutions. Through the IT solutions, the speed of certain tasks has been increasing while the pertaining human resources has been decreasing in a compulsory way. In parallel with these, administration has become almost fully transparent.

The other main achievement of the $4^{\text {th }}$ industrial revolution (information revolution) [3] is the accurate location at local, regional or even global level where network based services and beacon enabled tools, vehicles and people owning "smart" devices (e.g. mobiles, tablets, etc.), their location information can be fetched through remote monitoring services and the marking can be displayed in digital maps on a computer or mobile phone all over the world. This is not only providing features but initiates serious information security questions.

In our research, we will deal with the definition of the fleet and force monitoring terminology and the challenges that could impact the creation and adaptation of systems for supporting the public services.

\section{Definition of Fleet and Force Tracking Systems (FTS)}

Systems for the purposes of public services built by advanced technical and IT solutions are called fleet tracking systems, which are enabling the tracking of the devices and personnel of a given society organisation or business enterprise. A more complex term is

4 Information Technology. 
fleet management system, which still builds to advanced technical and IT solutions, but enables the tracking and management (planning, controlling, maintenance) of the whole fleet of a society organisation or business enterprise to optimise the resources. [4: 1] As per Karmazin, this can be interpreted in several ways; the wider interpretation is the handling of different tasks raised around vehicles (e.g. management, procurement, administration, vehicle tracking, maintenance, sales culling, etc.). Per a more specific interpretation, it is the management of different administrative tasks around the fleet. From a financial point of view, we speak about the cost around activities from a service provider, such as complex fleet renting and its associated tasks as service, licensing and fuel accounting. An advanced fleet management system has several functionalities like navigation, tracking (by geographic location and by activities carried out by the driver), protection against damage (vehicle theft or fuel theft), duplex communications channel between dispatcher and driver. It can also calculate routes, complete pre-calculations (estimated fuel using and time of arrival), be it used for control of fleet and drivers and their driving habits, record the actual driving/resting times in real time and create reports with alerts if needed. [4: 1-2] Due to the changing nature of the business sector and so of the technical improvements, it is almost impossible to find only fleet tracking systems. The simple tracking has been replaced by complex, fleet management systems with integrated services. After analysing multiple participants of the market, companies providing fleet management systems often use the term fleet tracking for their profile.

Primarily used in military terms, the (blue or own-neutral) force tracking systems are generally location positioning and reporting systems and their main function is sharing the actual geolocation information of units (sub-units, vehicles or even dismounted soldiers) with a periodic frequency refreshing and visualising those in digitalised maps so commanders and their staff can utilise this information making their situational awareness. The connected processes are executing automatically using advanced IT routines without the need of manual intervention from the users. [5: 5] [6]

It is valid to ask whether the only difference between fleet tracking and force tracking is the area of usage (civil or military terminology). By considering the definitions and understanding the complex task structure behind them, one can determine that the aim and the used technical solutions are very much similar within the two systems. Still, looking at their content and intension, there are basic differences between them. Even if both are used to increase the efficiency of "resource management", in the civil segment the focus is on the financial interest while in the military segment, the focus is on force protection and minimalising the human and material loss. Basically, fleet tracking systems are used to serve logistic purposes while force tracking systems are taking post-logistic tasks, as well (e.g. organising the re-supply). Other significant difference is the time factor. As for fleet management, the tasks can be pre-processed by the nature of the procedures on a daily, weekly or even monthly basis, while for force tracking systems, we can expect more emergency related tasks in combat situation. Last but not least, the stability and security of the systems are different within the two terms. The weight of the consequences defines the difference as a malfunction which for a fleet tracking system would end in financial or material loss, but in the military world, malfunction can take human lives (not only manpower but civilian lives present on the operational area as well). 
As per the above and per our understanding, fleet tracking is a public/sales driven logistic term and force tracking is for the command and control (C2) of armed forces and law enforcement organisations (military, police, disaster management). These latter organisations have strict hierarchical echelons and their characteristic of command is directing by orders (from the chain of command). Information gathered by force tracking systems are pushed forward to the battle management system (BMS), tactical mission management or search and rescue management systems as per the profile of the given organisation. ${ }^{5}$ Commanders with appropriate level of authority can make decisions based on this information and these orders can be passed to their subordinates or superiors (even neutrals) through that respective system. These could apply in the following situations:

- within disaster recovery, carrying out marching, rescue, discharge, protective and damage control tasks;

- within law enforcement, carrying out crime prevention and location securing tasks;

- within military, carrying out offensive, defensive and delaying defence tactics.

It is still worth mentioning even if it is not connected directly to the terminology but there are significant differences in the method of data flow and technical solutions used by fleet tracking and FTS. While fleet tracking systems use cellular networks or other $\mathrm{PMR}^{6}$ platforms, FTS use various spectrum of data transfer (i.e. $\mathrm{HF}^{7}$ and $\mathrm{VHF}^{8}$ networks, satellite channels) for passing geolocation information.

We would like to highlight, that the primary scope of our research is fleet and force tracking, which include specifying the geolocation position and displaying it on interactive maps, as well as the possibility of transfer and integration of data and its limitations. As we said earlier, these systems are integrated into the management or C2 system. The inspection of these complex systems is not in our current scope, only considering the necessary level of examination.

On the below table, you can see how fleet tracking and FTS are divided.

Table 1. Segmentation of fleet tracking and BFTS.

[Edited by the authors.]

\begin{tabular}{|l|c|l|l|l|}
\cline { 2 - 5 } \multicolumn{1}{c|}{} & \multicolumn{3}{c|}{ Fleet Tracking and FTS } \\
\cline { 2 - 5 } \multicolumn{1}{c|}{} & For public purposes & \multicolumn{3}{c|}{ For defensive purposes } \\
\hline Tracking level & Fleet tracking & \multicolumn{3}{c|}{ Force tracking } \\
\hline $\begin{array}{l}\text { Management/C2 } \\
\text { level }\end{array}$ & Fleet management & $\begin{array}{l}\text { Search and Rescue } \\
\text { Management } \\
\text { System (disaster } \\
\text { recovery) }\end{array}$ & $\begin{array}{l}\text { Tactical Mission } \\
\text { Management } \\
\text { System (law } \\
\text { enforcement) }\end{array}$ & $\begin{array}{l}\text { Battle Management } \\
\text { System (military) }\end{array}$ \\
\hline
\end{tabular}

After defining the terminologies, let us examine the nature of fleet and FTS and also their connection to public services from the relevant processes of information society point of view.

5 The two functions are often placed into an integrated system on a modular base, where a communication platform is also connected.

6 Personal Mobile Radio.

7 High Frequency: 3-30 MHz via International Telecommunication Union (ITU) normative.

8 Very High Frequency: 30-300 MHz via International Telecommunication Union (ITU) normative. 


\section{Information Society and Public Administration in the View of Fleet and Force Tracking Systems}

The information-industrial society is a new type of society and production model that is based on the continuous and intense usage of scientific results. This new model based on its content is called knowledge society and intense knowledge economy. [7]

The traditional industrial society is being replaced by this computer network and IT based production aeons, which intensively implements the scientific results and represents an extraordinarily high standard of production technologies. In this society, the determinative value and driving force is information and its compacted version, competence and science. [8: 78-79] From a $\mathrm{HR}^{9}$ point of view, the training of the new human workforce can take up to 20-30 years, because it requires more complex and higher competence (Lifelong Learning). It generates major structure changes in the society, it changes the life of people by even postponing the time when children move out from their parents and start their own family life.

Looking at the content of this information society, this is an enlightened and ultradeveloped society, which follows democratic rules. It can be characterised as a global economic society, which is built on the principle of private ownership and free market competition. Therefore, it is often called democratic global capitalism. The European Union has also been building the information society in the $21^{\text {st }}$ century. [8: 79] The newest scientific researches establish the possibility for creating a cutting-edge-computer network-based social management system. During the implementation of the rolling development plans, the European Union relies on a statistical observation system in which the development of each member state is being observed on a yearly basis and according to the statistical parameters of their results, they receive further goals to reach. The EU's ${ }^{10}$ integration economic system is the number one of the world due to the fact that the key sector of its economic force is the targeted supporting system. [8: 80]

The different aspects of information society have a wide range of literature, which will not be covered now in details due to space limitations. From this range, there is an outstanding early forerunner, Alvin Toffler, American sociologist, the creator of the social wave theory. In his theories, he marked the agricultural revolution to be the first world wave. It started about 10-12 thousand years ago and lasted until 1650. The agricultural yield stood at its Centrum while the field was the basis for power, so the social structure was typically feudalism. (This differs a bit from the feudalism described in the Hungarian education system, where they usually focus on a triangle of agriculture-terra-power.) The second wave started with the first industrial revolution between 1650 and 1950. This was the industrial society, which was the industrial production period founded on the traditional mass production. Its social model is industrial capitalism. The third wave is the information society, which currently has its preliminary phase as we estimate since 1950 until 2025 and it will last approximately for 100-200 years. In this new model of society, the hard, dangerous, monotone work will be performed by robots, while the human workforce will mainly cover the intellectual and creative works. [8: 80-81] [9]

\footnotetext{
$9 \quad$ Human Resources.

10 European Union.
} 
This is a global private equity and parliamentary democracy based on an economic system using advanced capitalist principles and is built on science, competence and networked information systems. This is not a form of government but a well-developed form of society and living. Its characteristics are as follows: it is fully digitalised, broadband (high transmission speed), multimedia, and electronic institutions are in place such as electronic (marked with "e”, i.e. e-public administration) state organisation, state government, state and local administration, court, public infrastructure, law enforcement organisations and tax authority. Its further attribution is the networking remote society, the members of which manage their private, public and corporate matters remotely due to the developed telecommunications and information networks. One of its main principles is the principle of authority, which requires proper authorisation for each mission in order to allow later prosecutions. Another principle is subsidiarity, which requires every decision to be delegated to the lowest possible level so that decisions can be made where they are most applicable. The different advanced fleet and force tracking solutions contribute to the fulfilment of these principles.

On the other hand, due to it is being ultra-developed, the information society is extremely vulnerable. It is exaggeratedly dependent on the developed, however, highly vulnerable information infrastructures, telecommunication or information systems and on their services. These systems can be in danger of a variety of functionality issues and of outages caused by deliberate damages or destruction. Due to their (strategic) central roles, they can be in target of business opponents at micro level and of hostile states, terrorists at macro level. Since the beginning of the year 2000, it has come into the public view that during these attacks all the following sections can be paralysed of a well networked country: its leadership, financial life, trade market and bank system, public transport and other logistical subsystems, power providing and public services' systems (gas, petrol, oil, electricity, water, sewer, tele-heating), raw material and food supply. Consequently, even health care can be faltered, public security can collapse and the previously organised functioning system falls apart. [8: 85-87] A good example for this is the malfunction of the basic public utilities on the east coast of the United States in August 2003. The nearly 3 days long power outages caused riots in some places. [10] [11] [12]

After the introduction of the different aspects and main characteristics of the information society, it is expedient to write about the categorisation of the different public service operators according to their fleet and tracking applications. To do this, of course, first it is required to define who these operators are. In Hungary we distinguish public servants in a specific and in a wider aspect, as well. In the wider sense, we consider the public service area composed of public servants, judges, prosecutors, military and public security professional members or career soldiers, members of secret and intelligence services, the full personnel of the public administration. In a more specific sense, only the personnel of the public administration belongs to the public service area, such as the public servants working in the public offices, the paramilitary and local government delegates and workers, the employees of the bodies carrying out public service activities (i.e. health care professionals, teachers) and the employees of state enterprises. [13: 3-5] [14: 1-2] It is necessary to mention that the usage of the above specific and wider sense is not unified neither in the European Union nor in the NATO literature. In the Anglo-Saxon literature, the word "public service" is used in the wider interpretation (i.e. doctors, teachers, policemen, public servants, etc.), 
while the expression "civil service" is used for the public servants according to the specific interpretation (i.e. clerks). [13: 4]

In our research, we are mainly dealing with the fleet and tracking solutions of the members of the public administration according to the wider interpretation. Based on a self-created model, we can categorise the public administration members from the fleet and force tracking systems’ point of view as per the following.

Public service belongs to the first group, such as the public servants and governmental officials employed by government organisations, offices (i.e. government offices, schools, hospitals, state enterprises, foundations, courts, prosecutions, etc.). Their common features are that during their fleet tracking tasks, it is sufficient to implement such commercial oriented services, that forward the data of tracking systems equipped with GPS ${ }^{11}$ or other satellite navigation systems via mobile broadband data connection. It is worth mentioning that in some cases (i.e. based on information security or availability point of view) the communication platform can be a closed-circuit network, TETRA. ${ }^{12}$

We list into the second group the systems of public security, the ambulance deployment and rescue management. Based on the provided services, they can be considered a transition between the fleet and tracking systems. Their common feature is that the circumstances of their usage is often not optimal because the moving and deployment units of the public security organisations can normally be required to act in damaged or destroyed infrastructures (i.e. earthquake, floods, storm) and also in some cases the operation management's work can be hardened with blocked communication channels by different groups with conflicting interests (criminal groups). Their further characteristic is that they can even implement the services of military systems in order to perform a successful task accomplishment. The primary communications platforms of these operation management systems are usually the TETRA systems.

We list the military bodies in the third group, the force tracking systems of these are usually used integrated into a Battle Management System.

As a fourth group, totally separately from the other groups, we list the secret services and intelligence agencies. The principal reason for this is the information sensitivity in relation to their actions.

\section{Fleet Tracking, FTS and other Applicable Supporting Systems in Public Services}

Nowadays, it is very common to use fleet tracking or FTS solutions in public services. Good examples are the PAJZS ${ }^{13}$ and DÖMI ${ }^{14}$ systems used within disaster management or National Ambulance Service' Rescue Control system, which partially is based on the EDR's ${ }^{15}$ (the Hungarian TETRA system), the fourth "governmental cellular network

\footnotetext{
Global Positioning System.

Terrestrial Trunked Radio.

Operations management decision support system.

On-duty decision support GIS.

Common Digital Radio Communication System.
} 
supplier", TETRA AVL ${ }^{16}$ solution. With the help of these systems, associates on duty could monitor the organisation's vehicles and coordinate tasks in almost real time.

The best example for personal tracking would be within criminal sentencing where the movement of people within house arrest are tracked and monitored using ankle bracelets in order to control the compliance of restrictions. The device, with proper network signal, can track the movement of people under house arrest. Another perfect example within fixed track transport is the information service of MÁV (Hungarian State Railways) called "Vonat Infó" where passengers can follow railroad traffic in real time. [15] Similar services are available within air transport. Flight radar 24 is an international service, which is often used domestically as well, provides a platform for tracking the movement of aircraft in international airspace, we also can search for their type (fixed or rotary wing), ID or other information. [16]

Tracking applications are also used in different areas of defence. Different FTS play a critical role in the missionary of Hungarian Defence Forces, like IFTS ${ }^{17}$ or FBCB2 BFT ${ }^{18}$ based on satellite communications used on the battlefields of Afghanistan, or KFTS ${ }^{19}$ used by allied police officers and military personnel based on TETRAPOL ${ }^{20}$ network in the battlefields of Kosovo. All the above examples are basically an IT based solution, therefore their development (and obsolescence) is showing an accelerating trend.

In our present-day life, many critical infrastructure and IT infrastructure systems have integrated different FTS services and their stability became the depository of safety. Luckily, the days of our lives pass peacefully but it is actually a fragile state, which is affected by multiple sources of danger. Let us just think about the migration crises afflicting our homes and the whole European Union or the large-scale, global climate change. These natural effects directly or indirectly could cause disturbance or damage in critical infrastructure. In order to minimise the consequences, specialists usually use military or other special technologies and systems.

During our research, we paid special attention to the implementation or military FTS solutions into public functions. As the information society we live in is threatened, the key for safety is the major reduction of known threats where adapting military technologies into different tasks is giving proper solution. Of course, it is possible to use developments from public functions into the expansion of different military systems and services. [17]

From previous results and professional experience, we have identified several research fields and challenges. In domestic location positioning, NAVSTAR, ${ }^{21}$ a USA based GPS still has a dominant role. Thanks to its coverage and reliability in the market of positioning systems, we find many GPS navigation or GPS escorting devices. However, recent studies highlighted the vulnerability of the above. [18] [19]

While in the middle of the $20^{\text {th }}$ century radio navigation was the privilege of air and navy forces (also flight and shipping), [19: 8-11] the second part of the century became the era of satellites for the global extension of navigation, and the first system was the satellite

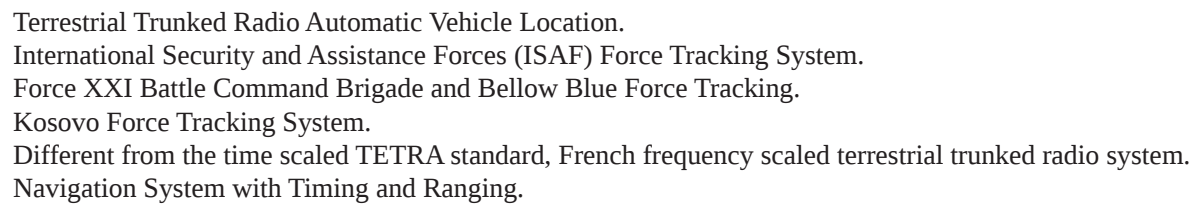


GPS of the United States. In 2001 it became available for public applications to receive punctual signals, giving a massive push for research and development and innovation, as well as the extension of the area of fields where we could use them. Without the trail-blazing services of GPS, we cannot imagine today's automatic positioning, fleet and BFT solutions.

At the same time, this service has its threats just to think about the extreme environment of satellites in space. On the $13^{\text {th }}$ of March 1989, due to a space storm, hundreds of satellites "vanished" and became out of service. [20] To use a not-so-extreme example as well, simple solar flares could also cause problems even in electrical networks like on the $23^{\text {rd }}$ of July 2016. [21]

Of course, not only the satellites are in danger of the disturbance coming from outer space, there are solutions blocking the services on Earth, as well. It is a widely known fact that GPS bugger equipment is available to buy even from the internet, which can make the puncture location identification in their radius impossible. In terms of the on purpose disturbances, the literature distinguishes jamming, spoofing, meaconing and the electromagnetic compatibility $(\mathrm{EMC})^{22}$ issues caused not on purpose by different interference sources. [18] [19] A partial solution can be for some issues the usage of GNSS $^{23}$ receivers, which are able to receive the signal of several global satellite navigation systems at the same time, so these calculate the location from the data received from more satellites. Other than the GPS, global coverage is also provided by the Russian GLONASS, ${ }^{24}$ the European Galileo or the Chinese Beidou (Compass) which provides partial coverage for now.

The aim of our research is to examine the possibilities of carrying out public functions from fleet and force tracking aspects with the usage of GNSS based satellite navigation systems, with special attention to the available geographical information systems (GIS). ${ }^{25}$ Professor Haig defines GIS as follows: "The GIS is a way of proceeding and also a device that is for location and state recorder of objects, for geographic phenomena on the surface of the Earth and near to it, to track the changes in space and time focusing on the effects of all above. Furthermore, it is to receive, store, manage, analyse and visualize the attributes and supplementary data of different content and in different formats.” [22: 75]

During the management processes to make the optimal decision one of the essential conditions is to set the proper situational awareness $\left(\mathrm{SA}^{26}\right)$. This can be deeply supported by GIS based interactive maps that show in real time the people and devices belonging to our responsibility. This is the reason for our analysis of the possible ways of utilisation of the special software that could raise the level of carrying out public functions.

According to our understanding, in relation to this, it is necessary to examine the possible ways to transfer the information provided by the fleet and tracking terminals. Considering the requirements and possibilities today, there are several solutions and channels for this purpose. The radios and radio communication systems working in HF are able to cover big distances at a relatively low cost. On the other hand, the creation and quality of the connection is greatly affected by meteorological factors and the momentary state

\footnotetext{
22 Electromagnetic Compatibility.

Global Navigation Satellite System.

Globalnaya Navigazionnaya Sputnikovaya Sistema (Global Navigation Satellite System).

Geographical Information Systems.

Situational Awareness.
} 
of the ionosphere while the available bandwidth is also strongly limited. Although these negative effects can be well counteracted by using modern digital modes [23] that are based on up-to-date adaptive and cognitive radio solutions. [24]

In addition to the HF devices, it is worth paying attention to the $\mathrm{UHF}^{27}$ radios, radio communication systems as well, which, however, ensure less range but provide faster data transfer speed. The establishment and maintenance of this type of connection can be determined in a lot deeper detail.

Obviously, we also plan to examine the data transfer possibilities via the up-todate mobile communication systems. Within this area, it is worth mentioning again the TETRA/TETRAPOL technologies used in different closed mobile communication systems. The TETRA standard was established between 1989-1993 by the European Telecommunication Standards Institute (ETSI), as such the digital Personal Mobile Radio $\left(\mathrm{dPMR}^{28}\right)$ system, that is able to replace the bigger private networked analogue radio systems i.e. analogue VHF/UHF solutions spread within the standby and public security bodies of the European countries. It is important to highlight that the TETRA standard does not set fix system parameters, it contains the services that must be provided by the system and the description of outer interfaces. So the TETRA systems of different countries and manufacturers may contain different solutions but we can state that their main technical parameters are nearly the same. [25] [26] In Hungary, since 1 February 2007, the Hungarian TETRA system has been working in its full set and came into the professional society as the Unified Digital Radio Communication System (EDR). The EDR covers more than 90\% of the country with 266 stationers and 5 mobile base stations. It serves 42,000 users with a 99.9\% availability indicator. [27: 3] Due to a framework (TETRA AVL) integrated into the EDR, it is possible to track the terminals in near real time. The Hungarian development of this service includes a great variety of possibilities in itself.

Moreover, there will be a great chance to improve the possibilities of TETRA systems. Expected from 2020, the TETRA LTE ${ }^{29}$ framework will be introduced, which will be able to provide wider bandwidth for the applications. It would be an excellent chance to build a modern closed-circuit wireless telecommunication network, which can support the mission critical communication, voice and data transfer, the applications (like on the smart phones), and the Big Bang ${ }^{30}$ in $\mathrm{IoT}^{31}$ Via this development, it will be able to effectively support the blue force tracking capability such as near-real time automatic tracking of the geolocation and the share of the data from the sensor networks (technical, medical). [28] [29]

In terms of the data transfer path, even the satellite communications services deserve special attention, which can ensure the required channels for fleet tracking even in the barely populated, remote from continental infrastructure or destroyed infrastructure (i.e. hit by disaster) areas. This solution requires a higher cost but the available bandwidth can be much bigger than in case of using the long distance HF systems. The connection setting and maintenance can be well determined.

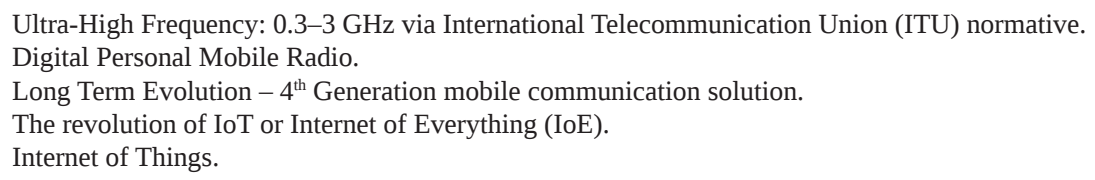


With the fast speed development of information technologies and miniaturisation, it became possible to satisfy such a demand that as a complementary service of the fleet tracking systems, we are able to track the firefighters participating in rescue, soldiers on the battlefield, policemen in deployment or even gain additional information about them in order to make optimal decisions. The aim of our research through examining the available technologies are the capabilities of systems and devices. Those are to define the services and possibilities through which the effectiveness of carrying out public services, the quality of work can be developed or the decision-making processes can be optimised. In relation to this, it is important to forward, process, evaluate and distribute the data gained from the terminals in a timely manner. In other words, the data fusion is an important question in order to own the information in the appropriate way and format by the experts and decision makers. To support this, the interoperability and need to share/need to know requires further research, which are generated by serious cybersecurity [30] [31] questions.

Another approach is to take opportunities in the field of sensor networks' applications. If we connect the FTS with sensor networks the data from these networks will be able to increase our situational awareness. From the point of view of force tracking systems, the best sensor networks capabilities are: medical monitoring and diagnostic networks (WBAN ${ }^{32}$ $\mathrm{WPAN}^{33}$ level), technical monitoring networks. There are many and more features that we can monitor, such as the temperature, pulse, blood pressure of the warriors, or the level of fuel/ammo/batteries of devices. We would like to research the application of IEEE 802.15.4 ZigBee and $\mathrm{LoRa}^{34}$ in the sensor networks, which can support the force tracking systems.

\section{Conclusion}

Through the exponential development of information technologies, it is possible to track people and technical devices nearly in real time. Using this skill in carrying out public services creates serious opportunities. On the other hand, it is also a well-known fact that several issues and impacts made on purpose or not, can endanger the secure functioning of these systems.

In our article, we defined the background of fleet and force tracking terminology and demonstrated the impacts of information society. We grouped the different organisations providing public services from the fleet and force tracking point of view. Also we determined the challenges of fleet and force tracking solutions as a basis for our future research.

In our paper, we analysed the development opportunities of tracking technologies. There is a serious potential in changing the GPS receivers to GNSS receivers. Moreover, we recommend increasing the deployment of the TETRA networks in the force tracking systems in the governmental sector.

Referring to the exponential trend of the IoT evolution, there will be a serious demand for data of sensor networks. Nowadays, the users of these fleet and force tracking systems

\footnotetext{
Wireless Body Area Network.

Wireless Personal Area Network.

Long Range.
} 
want to know the geolocation position of the people and vehicles. We think it will be a basic feature to support the tracking systems with sensor data in the not-too-distant future.

We think our publication indicated more research topics, for example, as we determined previously, the separation of the technical features of the four governmental groups.

\section{References}

[1] BUDAI B. B.: Az e-közigazgatás elmélete. Budapest, Akadémiai Kiadó, 2014. DOI: https:// doi.org/10.1556/9789630597852

[2] NEMESLAKI A. szerk.: E-közszolgálat fejlesztés: Elméleti Alapok és tudományos kutatási módszerek. Budapest, Nemzeti Közszolgálati Egyetem, 2014.

[3] HUSI G.: Ipar 4.0. Debrecen, Debreceni Egyetem, 2016. www.eng.unideb.hu/userdir/vmt2/ images/tantargyak/robottechnika/Ipar\%204.0\%20jegyzet.pdf (Downloaded: 29.11.2016)

[4] KARMAZIN Gy.: Flotta menedzsment rendszerek bevezetése és pozitív hatásai. Logisztikai Trendek és Legjobb Gyakorlatok, 6. (2015). http://logisztikaitrendek.hu/wp-content/ uploads/2015/06/Flotta-menedzsment-rendszerek.pdf (Downloaded: 04.12.2016)

[5] KÁROLY K.: NATO hadseregek Erökövetési Rendszerei a honi alkalmazhatóság tükrében. Székesfehérvár, Magyar Honvédség Összhaderőnemi Parancsnokság, 2015.

[6] GULYÁS A.: Force Tracking System in SOF applications. AARMS, 84 (2009), 601-617. https://docplayer.net/1474320-Force-tracking-system-in-sof-applications.html (Downloaded: 25.05.2017)

[7] HAIG Zs. - VÁRHEGYI I.: A vezetési hadviselés alapjai. Budapest, Zrínyi Miklós Nemzetvédelmi Egyetem, 2000.

[8] HAIG Zs. - VÁRHEGYI I.: Információs Műveletek. I. kötet. Egyetemi jegyzet. Budapest, Zrínyi Miklós Nemzetvédelmi Egyetem, 2004.

[9] TOFFLER, A.: A harmadik hullám. Budapest, Typotex Press, 1980.

[10] NYIKES Z. - RAJNAI Z.: The Big Data and the Relationship of the Hungarian National Digital Infrastructure. In PAVLOVIĆ, M. ed.: International Conference on Applied Internet and Information Technologies: ICAIIT 2015. Proceedings. Zrenjanin, University of Novi Sad, 2015. 6-12.

[11] BARRON, J.: The Blackout of 2003: The overview; power surge blacks out Northeast, hitting cities in 8 states and Canada; midday shutdowns disrupt millions. New York Times, 15.08.2003. www.nytimes.com/2003/08/15/nyregion/blackout-2003-overview-power-surgeblacks-northeast-hitting-cities-8-states.html (Downloaded: 04.12.2016)

[12] HAIG Zs. - KOVÁCS L.: Kritikus Infrastruktúrák és Kritikus Információs Infrastruktúrák. Budapest, Nemzeti Közszolgálati Egyetem, 2012. www.uni-nke.hu/document/uni-nke-hu/ kritikus_infrastrukturak.pdf (Downloaded: 04.12.2016)

[13] LINDER V.: A magyar közszolgálat humánerőforrás-gazdálkodásának egyes kérdései - nemzetközi összehasonlításban. Ecostat Kormányzati Gazdaság- és Társadalomstratégiai Kutató Intézet. Időszaki Közlemények, 31 (2008), 55. http://mkksz.org.hu/html/ main/alkossunk/vitainspirator/0412/linder_viktoria.pdf (Downloaded: 04.12.2016)

[14] CZÉKMANN Zs.: A közigazgatás személyzete: a közszolgálat. Miskolc, Miskolci Egyetem, 2010. 
K. KÁROLY, A. NÉMETH: The Possibilities of Supporting the Public Functions with Fleet...

[15] MÁV-START Zrt. Vonat Infó. Webpage. http://vonatinfo.mav-start.hu/ (Downloaded: 06.12.2016)

[16] Flight Radar 24. Webpage. www.flightradar24.com (Downloaded: 06.12.2016)

[17] SZABÓ A.: A kiberbiztonság oktatásának kérdése a Kiber-Elektromágneses tevékenység (Cyber Electromagnetic Activities) tükrében. Konferencia előadás. In Robothadviselés 2016. Budapest, Nemzeti Közszolgálati Egyetem, 2016. http://robothadviseles.hu/RW16_abstracts/ abstract_Szabo.pdf (Downloaded: 06.12.2016)

[18] VÁNYA L.: A múholdas helymeghatározó rendszerek elektronikai hadviselési kérdései. Repüléstudományi Közlemények, 282 (2016). www.repulestudomany.hu/ folyoirat/2016_2/2016-2-09-0308_Vanya_Laszlo.pdf (Downloaded: 06.12.2016)

[19] VÁNYA L.: Navigációs berendezések zavarása és megtévesztése. Repüléstudományi Közlemények, 272 (2015), 7-16. http://epa.oszk.hu/02600/02694/00068/pdf/EPA02694_ rtk_2015_2_007-016.pdf (Downloaded: 06.12.2016)

[20] ODENWALD, S.: The Day the Sun Brought Darkness. Washington, D.C., NASA, 2009. www.nasa.gov/topics/earth/features/sun_darkness.html (Downloaded: 07.12.2016)

[21] TÓTH I.: A 2016-os év eddigi legnagyobb napkitörése. Csillagászat.hu, 26.06.2016. www. csillagaszat.hu/hirek/nr-egyeb-naprendszer/nr-nap/a-2016-os-ev-eddigi-legnagyobbnapkitorese/ (Downloaded: 07.12.016)

[22] HAIG Zs.: Az elektronikai harc térinformatikai adatbázisa. Hadtudomány, 4 (1996), 75-83.

[23] NÉMETH A. - KÁROLY K.: Korszerű rövidhullámú harcászati rádióeszközök erőkövető rendszerekben való alkalmazhatóságának vizsgálata. Honvédségi Szemle, 1446 (2016), 65-78.

[24] GULYÁS A.: Kognitív üzemmódok katonai alkalmazása. Seregszemle, 141 (2016), 59-76. https://honvedelem.hu/kiadvany/seregszemle_2016_1 (Downloaded: 11.12.2016)

[25] TETRA. European Telecommunications Standards Institute official website. www.etsi.org/ technologies-clusters/technologies/tetra (Downloaded: 08.11.2014)

[26] JOBBÁGY Sz. - SEREGE G.: Az egységes készenléti digitális trönkölt rádiórendszer, TETRA és TETRAPOL jellemzői, sajátosságai. In Kommunikáció 2003. Budapest, 2003. 119-132.

[27] BALLA F.: Információ és üzembiztonság a kommunikáció terén, EDR - A készenléti szolgálatok egységes és egyetlen vezeték nélküli híradó rendszere. Előadás. Budapest, Pro-M Zrt, 2014. http://bte.hu/files/2014_03_10_Informci_s_zembiztonsg_a_kommunikci_ tern_1_v.pdf (Downloaded: 11.06.2015)

[28] ROHILL: LTE for critical communication. White paper, Issue 1. Hoogeveen, LTEtraNode, 2015.

[29] GULYÁS A.: Gondolatok az adatátviteli rendszerek fejlődéséről. Seregszemle, 152 (2017), 162-168.

[30] DÉVAI D.: The U.S. Response to the 2016 Russian Election Meddling and the Evolving National Strategic Thought in Cyberspace (Part 1). AARMS, 181 (2019), 39-57. https:// folyoiratok.uni-nke.hu/document/nkeszolgaltato-uni-nke-hu/AARMS_2019_01_03_DoraDeVAI1.pdf (Downloaded: 23.06.2019) DOI: https://doi.org/10.32565/aarms.2019.1.3

[31] DÉVAI D.: The U.S. Response to the 2016 Russian Election Meddling and the Evolving National Strategic Thought in Cyberspace (Part 2). AARMS, 181 (2019), 59-77. https:// folyoiratok.uni-nke.hu/document/nkeszolgaltato-uni-nke-hu/AARMS_2019_01_03_DoraDeVAI1.pdf (Downloaded: 23.06.2019) DOI: https://doi.org/10.32565/aarms.2019.1.4 